\title{
Uji Daya Hasil Varietas Lokal Tembakau Bondowoso
}

DOI 10.18196/pt.2016.050.7-13

\author{
Sri Yulaikah dan Andi Muhammad Amir \\ Balai Penelitian Tanaman Pemanis dan Serat, Jalan Raya Karangploso, Kotak Pos 199 \\ Malang, Jawa Timur 65152; Email: sriyulaikha@gmail.com
}

\begin{abstract}
ABSTRAK
Tembakau Bondowoso merupakan tembakau rajangan yang berkembang di 11 kecamatan yaitu kecamatan Bondowoso, Tenggarang, Tegal Ampel, Pakem, Curahdami, Maesan, Pujer, Wonosari, Binakal, Taman Krocok dan Wringin. Untuk mendukung pengembangan varietas lokal tersebut perlu dilakukan kegiatan uji daya hasil varietas. Penelitian ini bertujuan untuk mengetahui daya hasil varietas-varietas lokal, keunggulan-keunggulan sifat yang dimiliki dan memilih yang terbaik. Penelitian dilaksanakan mulai bulan Maret sampai dengan September 2009 di daerah pengembangan tembakau lokal yang telah lama diusahakan. Varietas yang diuji terdiri dari 6 varietas, yaitu Sam 1, Se2, Mar3, Sam4, Sam5, dan Sam6, disusun dalam rancangan acak kelompok (RAK), dan diulang tiga kali. Masing masing petak terdiri dari 200 tanaman. Hasil penelitian menunjukkan dari enam varietas yang diuji, tiga varietas lokal memiliki kelebihan yang seimbang dari segi potensi produksi, indeks mutu, indeks tanaman, kadar nikotin dan serangan penyakit, yaitu Sam1, Sam5 dan Sam6, dengan daya hasil masing-masing 1.682 kg/ha, 1.399 kg/ha dan 1,282 kg/per ha.

Kata Kunci: Tembakau, Bondowoso, Uji daya hasil
\end{abstract}

\begin{abstract}
Bondowoso tobacco is a type of sliced tobacco that is developed in eleven district i.e. Bondowoso, Tenggarang, Tegal Ampel, Pakem, Curahdami, Maesan, Pujer, Wonosari, Binakal, Taman Krocok and Wringin. In order to fulfill the improvement of new variety program, yield evaluations is a step that should be done. The aims of the experiment were to examine the yield of local varieties, the superior traits and then choose the best variety. The experiment was conducted on March to September 2009 in tobacco producing areas. The experiment tested 6 local varieties i.e. Sam1, Se2, Mar3, Sam4, Sam5 and Sam6. Each of them was plant with three replicates. The experiment design was randomized complete block design (RCBD). Each plot consisted of 200 plants. The result showed that three varieties of which relatively had the same superiority on characters: yield potensial, quality index, plant index, nicotine content and disease tolerance. The selected varieties were Sam1, Sam5 dan Sam6, with yield potensial each acession i.e: 1.682 kg/ha, 1.399 kg/ha and $1.282 \mathrm{~kg} / \mathrm{ha}$.

Keywords: Tobacco, Bondowoso, Yield evaluation
\end{abstract}

\section{PENDAHULUAN}

Tembakau Bondowoso berdasarkan tipe tembakau dikelompokkan menjadi dua kelompok yaitu tembakau rajangan dan tembakau kasturi. Tembakau rajangan tersebar di kecamatan Bondowoso, Tenggarang, Tegal Ampel, Pakem, Curahdami, Maesan, Pujer, Wonosari, Binakal, Taman Krocok dan Wringin. Tembakau Kasturi berkembang di kecamatan Tamanan, Pujer, Tapen dan Tlogosari. Tembakau Kasturi dijual dalam bentuk krosok sedang tembakau rajangan dijual dalam bentuk rajangan halus dan rajangan kasar. Tembakau Bondowoso sebagian besar merupakan bahan baku pabrik rokok kretek.
Dalam blending rokok, tembakau rajangan Bondowoso merupakan tembakau nasi, dibutuhkan dalam proporsi yang relatif banyak, berfungsi sebagai pengisi (filler) atau biasa disebut tembakau nasi (Suwarso, 1992), sedangkan tembakau yang memberi rasa yaitu tipe tembakau yang memiliki kadar nikotin tinggi seperti tembakau Temanggung dan tembakau Ploso, dinamakan tembakau lauk.

Areal pengembangan tembakau rata-rata tiap tahun berkisar antara 5.000 ha sampai dengan 7.000 ha per tahun (Disbun Bondowoso, 2011). Kendala pengembangan komoditi tanaman tembakau adalah terdapat bermacam-macam 


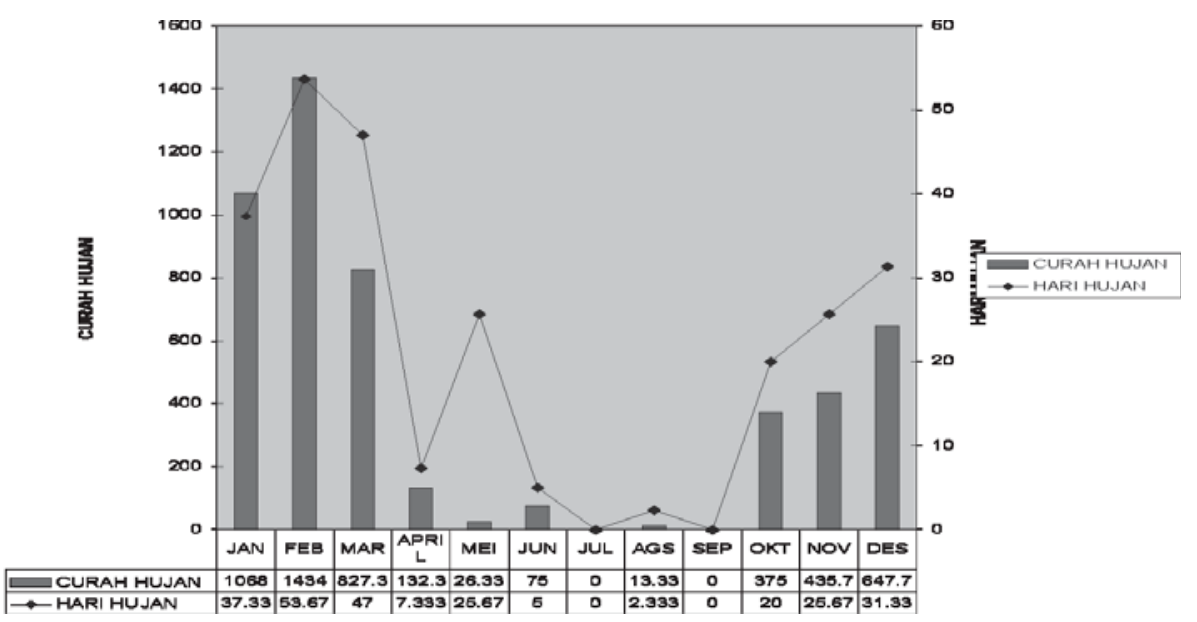

Gambar 1. Data Curah Hujan Kabupaten Bondowoso Tahun 2009

varietas lokal yang belum diketahui tingkat produktivitas dan mutu masing-masing varietas lokal. Oleh karena itu, diperlukan upaya pemilihan varietas lokal yang unggul yang bisa menjadi pilihan petani agar lebih menguntungkan.

Secara umum kegiatan pemuliaan dimaksudkan untuk mendapatkan varietas unggul sehingga bisa meningkatkan keuntungan bagi pengguna, (Mangoendidjojo, 2003; Allard, 1989; Crowder, 1986). Langkah-langkah yang ditempuh pertama kali adalah pengumpulan materi genetik yang digunakan untuk kegiatan pemuliaan. Kemudian dilakukan evaluasi, sedang untuk mengetahui potensi dan mutu dilakukan uji adaptasi. Pada penelitian ini eksplorasi telah dilakukan pada tahun 2008 (Yulaikah et al., 2008). Uji adaptasi merupakan rangkaian kegiatan yang biasanya ditindak lanjuti dengan uji multi lokasi, seperti yang dilakukan pada tembakau Virginia, varietasvarietas tersebut sebelum diuji multi lokasi terlebih dahulu dilakukan pengujian-pengujian uji daya hasil (Suwarso, et al., 2004), pada tembakau Virginia (Suwarso, 1992); tembakau madura (Suwarso et al., 1996); tembakau orien- tal (Suwarso, et al., 2010). Lanjutan dari uji multi lokasi setelah ditemukan varietas-varietas yang stabil, dilakukan pelepasan varietas, karena komersialisasi varietas tidak bisa dilakukan sebelum varietas tersebut dilakukan pelepasan varietas.

Varietas-varietas lokal hasil eksplorasi merupakan kekayaan daerah, yang pada era global ini kekayaan tersebut perlu dilindungi. Apabila tidak segera dilindungi, tidak menutup kemungkinan akan dilindungi oleh orang asing. Menurut undang-undang apabila dua permohonan perlindungan varietas yang sama diajukan, maka yang dianggap sah adalah pemohon pertama.

Tujuan dari penelitian ini adalah mengetahui daya hasil varietas-varietas lokal tembakau Bondowoso dan memilih yang terbaik

\section{BAHAN DAN METODE}

Penelitian dilaksanakan pada bulan Maret sampai dengan September 2009. di di Desa Karang Anyar, Kecamatan Tegal Ampel, Kabupaten Bondowoso. Kondisi iklim tahun 2009 sedang dalam arti pada saat tanam, kondisi 
air masih tercukupi dan pada saat panen tanaman tidak terkena hujan. Adapun sebaran curah hujan dan hari hujan diperlihatkan pada Gambar 1.

Varietas yang diuji terdiri atas 6 varietas lokal, yaitu Sam1, Se2, Mar3, Sam4, Sam5 dan Sam6. Percobaan disusun dengan menggunakan rancangan acak kelompok (RAK) dan diulang tiga kali. Masing masing petak terdiri atas200 tanaman. Jarak tanam yang digunakan $90 \mathrm{~cm} \mathrm{x}$ $40 \mathrm{~cm}$. Pemupukan menggunakan dosis $300 \mathrm{~kg}$ ZA, $100 \mathrm{~kg}$ urea, $200 \mathrm{Kg}$ SP-18 dan $50 \mathrm{Kg}$ ZK per hektar.

Pengamatan meliputi produksi, indeks mutu dan indeks tanaman. Untuk menghitung indeks mutu mengacu penelitian (Suwarso, et al., 2004). Indeks mutu dihitung berdasarkan grade sesuai untuk konsumen dalam hal ini adalah pabrik rokok dengan persamaan:

Indeks mutu $=\frac{\sum_{\mathrm{i}=1}^{\mathrm{n}}(\mathrm{Ai} \times \mathrm{Bi})}{\sum_{\mathrm{i}=1}^{\mathrm{n}}(\mathrm{Bi})} \times 100 \%$

Selain dilakukan pengamatan tersebut di atas, juga dilakukan pengerodongan individu tanaman yang akan digunakan sebagai bahan uji daya hasil lanjutan. Pengambilan sampel tanaman untuk diambil benihnya dilakukan sesuai standard baku seleksi tanaman menyerbuk sendiri (Suwarso, 1981)

Pelaksanaan lapang dimulai dari pembuatan pesemaian. Pesemaian dilaksanakan di dekat lahan agar mudah dalam pemeliharaan.
Pengolahan tanah untuk pertanaman dilakukan 2 kali dengan interval 2-3 minggu. Setelah pengolahan ke dua, tanah dibiarkan selama seminggu. Got melintang selebar $30 \mathrm{~cm}$ dengan kedalaman $30 \mathrm{~cm}$. Jarak antar got disesuaikan dengan ukuran petak percoban. Di bagian tepi dibuat got keliling dengan lebar $40 \mathrm{~cm}$ dan dalam 40-50 cm. Setelah tanah diolah, dibuat guludan single row, dengan jarak antar tanaman dalam barisan $40 \mathrm{~cm}$. Jarak barisan 90 $\mathrm{cm}$. Penanaman dilakukan pada sore hari.

Penyulaman dilakukan antara 5 - 10 hari setelah tanam. Apabila terpaksa, penyulaman masih dapat dilakukan sampai umur 14 hari setelah tanam, setelah itu dianjurkan tidak dilakukan penyulaman lagi. Penyiraman dilakukan setiap hari selama 5 hari. Setelah tanaman terlihat hidup, penyiraman dilakukan dengan interval 5-7 hari sampai tanaman berumur 1 bulan. Setelah itu penyiraman dilakukan 7 hari sekali atau bila diperlukan saja. Pupuk SP-18 diberikan sebelum tanam dengan dosis $200 \mathrm{~kg} / \mathrm{ha}$. Pemupukan selanjutnya masing-masing dengan dosis $300 \mathrm{~kg} / \mathrm{ha}$ ZA, 100 $\mathrm{kg} /$ ha urea dan $50 \mathrm{~kg} / \mathrm{ha} \mathrm{ZK}$ yang diberikan pada umur 7-10 hari dan 21 hari setelah tanam masing-masing setengah dosis. Pemberian pupuk kira-kira $10 \mathrm{~cm}$ dari pangkal batang menggunakan tugal. Setiap selesai memupuk, lubang pupuk ditutup kembali. Pendangiran dan pembumbunan dilakukan paling sedikit 2 kali yaitu setelah pemupukan ZA pertama dan kedua. Setelah itu, masih dapat dilakukan pendangiran, terutama bila terlihat tanah di sekitar pangkal batang memadat. Pengendalian terhadap Phytophthora nicotianae menggunakan fungisida Ridomil MZ dengan konsentrasi $5 \mathrm{~g} / 1$ air, disemprotkan pada pangkal batang, dengan dosis penyemprotan 2,5 1/ha. Pengendalian terhadap Helicoverpa armigera dan Spodoptera 
Tabel 1. Umur Berbunga, Tinggi Tanaman, Jumlah, Panjang dan Lebar Daun dari Berbagai Varietas Tembakau yang Diuji di Desa Karang Anyar, Kec. Tegal Ampel, Kab. Bondowoso pada tahun 2009

\begin{tabular}{clllll}
\hline Varietas & $\begin{array}{l}\text { Umur berbunga } \\
\text { (hari) }\end{array}$ & $\begin{array}{l}\text { Tinggi tanaman } \\
(\mathrm{cm})\end{array}$ & $\begin{array}{l}\text { Jumlah daun } \\
\text { (lembar) }\end{array}$ & $\begin{array}{l}\text { Panjang daun } \\
(\mathrm{cm})\end{array}$ & $\begin{array}{l}\text { Lebar daun } \\
(\mathrm{cm})\end{array}$ \\
\hline Sam1 & 80,87 & $172,30 \mathrm{a}$ & $27,60 \mathrm{ab}$ & 55,20 & $26,50 \mathrm{ab}$ \\
Se2 & 78,86 & $114,30 \mathrm{~b}$ & $27,30 \mathrm{~b}$ & 49,60 & $29,00 \mathrm{ab}$ \\
Mar3 & 81,00 & $112,80 \mathrm{~b}$ & $24,30 \mathrm{c}$ & 54,00 & $29,00 \mathrm{ab}$ \\
Sam4 & 79,33 & $172,80 \mathrm{a}$ & $29,40 \mathrm{a}$ & 51,70 & $25,60 \mathrm{~b}$ \\
Sam5 & 79,67 & $158,00 \mathrm{a}$ & $25,80 \mathrm{bc}$ & 53,70 & $29,90 \mathrm{a}$ \\
Sam6 & 79,33 & $175,40 \mathrm{a}$ & $25,70 \mathrm{bc}$ & 51,20 & $29,50 \mathrm{ab}$ \\
KK (\%) & tn & 6,9 & 7,2 & $\mathrm{tn}$ & 7,4 \\
\hline
\end{tabular}

litura menggunakan insektisida Lannate dengan konsentrasi $1,5 \mathrm{~g} / \mathrm{l}$ air, dosis $540 \mathrm{~g} / \mathrm{ha}$. Sementara pengendalian terhadap Myzus persicae menggunakan insektisida Confidor WP dengan konsentrasi $5 \mathrm{~g} / 101$ air untuk 100 tanaman, dengan dosis $600 \mathrm{~g} / \mathrm{ha}$. Pemberian insektisida Confidor WP dengan cara disiramkan, pada saat tanaman berumur 10 hari. Ketiga jenis hama tersebut, dilakukan pengendalian dengan cara penyemprotan menggunakan knapsack bertekanan tinggi pada saat tanaman berumur 10 hari agar tanaman tembakau terhindar dari serangan $\mathrm{M}$. persicae yang merupakan vektor dari virus Cucumber Mozaic Virus (CMV) yang dapat menyebabkan penurunan kualitas dan kuantitas daun (Kalshoven, 1981). Pembuangan sirung dilakukan secara periodik, paling lambat 5 hari sekali. Panen daun dilakukan sesuai dengan kemasakan daun. Sebelum dirajang terlebih dahulu daun diperam hingga menguning. Perajangan dilakukan malam hari sehingga penjemuran bisa dilakukan dengan baik.

\section{HASIL DAN PEMBAHASAN}

Penelitian tahun tanam 2009 kondisi iklim normal artinya keadaan air sesuai dengan kebutuhan tembakau, tidak terlalu basah (curah hujan tidak terlalu tinggi) dan tidak terlalu kering (curah hujan tidak terlalu rendah), sehingga pertanaman tahun tersebut memperoleh tembakau bermutu baik dibanding tahun-tahun yang lain. Tanaman tembakau pada awal pertumbuhan memang membutuhkan air untuk pertumbuhannya terutama pada saat setelah transplanting, yaitu perpindahan dari pesemaian ke lapang. Setelah tanaman hidup diperlukan pengairan satu atau dua kali setelah itu tanaman bisa dibiarkan hidup sampai panen.

Pada kondisi curah hujan sesuai dengan kebutuhan tanaman tembakau, penentuan waktu tanam tembakau tidak menjadi masalah. Waktu tanam awal (seri 1), atau tengah (seri 2), pertumbuhan tanaman umumnya baik, dan memperoleh mutu tembakau yang baik. Penanaman akhir ( seri 3) biasanya pertumbuhan pertanaman baik, tetapi yang menjadi masalah adalah pasar. Jika pasar masih terbuka artinya masih ada pembeli tidak ada masalah. Biasanya jika pasar sudah tercukupi pasoknya maka harga akan menurun.

\section{Karakter Morfologi Tanaman}

Pengamatan pada saat bunga mekar pertama menunjukkan bahwa umur berbunga tidak berbeda nyata antar varietas. Rata-rata tanaman tembakau berbunga pada umur sekitar 78,86 hari sampai 81 hari setelah tanam. Tinggi 
tanaman bervariasi antara $112,8 \mathrm{~cm}$ (rendah) sampai 175,4 cm (tinggi). Dari 6 varietas lokal, 4 varietas termasuk kategori tinggi dan 2 varietas tergolong rendah. Jumlah daun dan lebar daun bervariasi antar varietas lokal, sedang panjang daun secara statistik tidak menunjukkan perbedaan yang nyata baik tanaman yang tinggi maupun rendah, panjang daunnya berkisar antara sampai 49,6 cm sampai 55,8 cm. Ukuran daun dan jumlah daun biasanya mempengaruhi tingkat produktivitas suatu varietas, pernyataan ini sesuai dengan penelitian Herwati et al. (1993). Satu karakter lagi penentu tinggi rendahnya produksi yaitu ketebalan daun. Hasil analisa karakter morfologi masing-masing varietas lokal disajikan pada Tabel 1 .

Koefisien keragaman rendah dikarenakan saat berbunga dalam waktu yang serentak, dan keseragaman dalam satu varietas termasuk tinggi. Keragaman tanaman antar varietas terlihat pada penampilan tinggi tanaman , jumlah daun dan lebar daun. Pada umur tanaman sekitar satu bulan, belum terlihat perbedaan antar varietas, setelah tanaman menjelang umur 78 hari, mulai terlihat karakter masing-masing, oleh karena itu pengamatan karakter tanaman dilakukan pada saat bunga mekar pertama. Setelah melampaui masa-masa tersebut penampilan tanaman biasanya berubah seperti sudut daun, permukaan daun dan ujung daun sehingga untuk mencari penciri suatu varietas menemui sedikit kesulitan.

Pada musim dimana curah hujan tidak terlalu basah dan tidak terlalu kering maka penampilan karakter tanaman terekspresi dengan jelas. Berbeda dengan musim hujan dimana kondisi tanah sangat basah maka keadaan demikian menyebabkan penampilan ciri-ciri khusus suatu varietas terekspresi kurang jelas. Misalnya ciri-ciri tanaman mestinya tinggi hanya sekitar satu meter, dengan kondisi tanah yang basah tanaman akan menjadi tinggi, sehingga akan mempengaruhi ciri-ciri yang lain misalnya kadar nikotinnya akan turun menjadi lebih rendah dibanding kadar nikotin biasanya. Karakter-karakter yang lain misalnya bentuk daun jika musim normal akan terekspresi dengan jelas.

Produksi, Indeks Mutu dan Indeks Tanaman

Hasil perhitungan produksi per ha menunjukkan bahwa kisaran produksi varietas yang diuji antara $1.292 \mathrm{~kg} /$ ha (terendah) sampai dengan $1.682 \mathrm{~kg} /$ ha (tertinggi). Indeks mutu berkisar antara 64,16 sampai dengan 72,75 dan indeks tanaman 90,35 sampai dengan 113,07. Hasil pengamatan disajikan pada Tabel 2.

Tabel 2. Produksi, Indeks Mutu dan Indeks Tanaman Tembakau Berbagai Varietas di Desa Karang Anyar, Kec. Tegal Ampel, Kab. Bondowoso pada Tahun 2009

\begin{tabular}{lllr}
\hline Varietas & $\begin{array}{l}\text { Produksi } \\
(\mathrm{kg} / \mathrm{ha})\end{array}$ & $\begin{array}{l}\text { Indeks } \\
\text { mutu }\end{array}$ & $\begin{array}{c}\text { Indeks } \\
\text { tanaman }\end{array}$ \\
\hline Sam1 & 1.682 & 64,16 & 107,89 \\
Se2 & 1.292 & 70,10 & 90,35 \\
Mar3 & 1.554 & 72,75 & 113,07 \\
Sam4 & 1.321 & 71,58 & 94,51 \\
Sam5 & 1.399 & 71,50 & 100,13 \\
Sam6 & 1.282 & 72,10 & 92,70 \\
KK (\%) & tn & tn & tn \\
\hline
\end{tabular}

Pemilihan varietas lokal yang diuji salah satunya didasarkan pada indeks tanaman. Hasil tembakau rajangan dari varietas yang diuji dinilaikan ke salah satu pabrik rokok yang ada di daerah setempat. Tingkat harga yang diperoleh dari pabrik rokok tersebut merupakan penilaian pabrik terhadap mutu suatu varietas. Semakin tinggi grade suatu varietas yang dinilaikan semakin tinggi indeks harga. Untuk memperoleh indeks mutu yang tinggi 
disyaratkan selain indeks harga tinggi, produksi per satuan luas per tahap panen diharapkan tinggi. Sementara indeks tanaman adalah perkalian antar indeks mutu dikalikan produksi per hektar. Oleh karena itu harga sangat menentukan indeks mutu dan indeks tanaman.

Dari data tersebut di atas menunjukkan bahwa indeks mutu dan indeks tanaman tidak berbeda nyata. Sementara variasi produksi tidak terlalu tinggi, walaupun secara statistik berbeda nyata, karena faktor-faktor yang menentukan tinggi rendahnya indeks mutu dan indeks tanaman adalah kedua faktor tersebut di atas.

Jika indeks mutu dan indeks tanaman tidak berbeda nyata, maka perlu dicermati faktor lain yang menjadi bahan pertimbangan. Dari hasil observasi petani menjelaskan bahwa dari enam varietas tersebut varietas samporis adalah yang banyak ditanam oleh petani. Hasil analisa kadar nikotin pada berbagai varietas disajikan pada Tabel 3.

Tabel 3. Analisa Kadar Nikotin Berbagai Varietas Tembakau yang Diuji di Desa Karang Anyar, Kec.Tegal Ampel, Kab. Bondowoso pada Tahun 2009

\begin{tabular}{|c|c|c|c|c|}
\hline \multirow[t]{2}{*}{ Varietas } & \multicolumn{4}{|c|}{$\begin{array}{l}\text { Kadar } \\
\text { nikotin (\%) }\end{array}$} \\
\hline & Panen I & Panen II & Panen III & Panen IV \\
\hline Saml & 2,35 & 2,07 & $2,02 b$ & 1,45 \\
\hline Se2 & 2,30 & 2,07 & $2,22 a b$ & 1,71 \\
\hline Mar3 & 2,66 & 2,01 & $2,43 a$ & 1,74 \\
\hline Sam4 & 2,79 & 2,62 & $1,97 \mathrm{~b}$ & 1,64 \\
\hline Sam5 & 2,01 & 2,30 & $2,29 a b$ & 1,48 \\
\hline Sam 6 & 2,61 & 2,27 & $2,45 a$ & 1,70 \\
\hline KK (\%) & tn & tn & 9,0 & tn \\
\hline
\end{tabular}

Dilihat dari kadar nikotin yang diambil sampel dari beberapa kali panen kadar nikotin Sam1, Se2 dan Sam5 tidak pernah mencapai kadar nikotin tertinggi. Sam6, Sam4 dan Mar4 dalam tiga kali panen mencapai kadar nikotin tertinggi sampai dua kali (Tabel 3). Peneliti lain menyebutkan bahwa tinggi rendahnya kadar nikotin pada tanaman tembakau dipengaruhi oleh faktor genetik, budidaya dan lingkungan (Suwarso, et al., 2010).

Kadar nikotin varietas lokal Bondowoso tergolong rendah berkisar antara 1,45 \% sampai dengan 2,79\%, dari 6 varietas lokal kadar nikotin hampir tidak berbeda nyata, namun pada panen ada perbedaan antar varietas lokal. Kadar nikotin tertinggi dicapai oleh Sam6 yang tidak beda nyata dengan Mar3. Kadar nikotin terendah terdapat pada Sam1 dan Sam4, namun tidak beda nyata dengan Sam5 dan Se2. Jika indeks tanaman tidak beda nyata, pengambilan keputusan bisa berdasarkan faktor lain, seperti kadar nikotin atau ketahanan terhadap serangan hama dan penyakit.

Ketahanan juga merupakan penentu pemilihan varietas setelah indeks tanaman. Walaupun indeks tanaman tinggi jika ketahanan terhadap penyakit rendah suatu varietas belum tentu terpilih, karena serangan hama penyakit akan menurunkan produktivitas. Hasil penelitian Semangun (1991) menyebutkan bahwa pada serangan penyakit (virus) tanaman tembakau bisa menurunkan produksi hingga $60 \%$. Pengamatan terhadap serangan penyakit, mulai umur satu bulan, sejak pengairan tanaman ada yang mengalami layu. Hasil pengamatan serangan penyakit kemudian diamati di laboratorium, ternyata penyakit yang menyerang adalah bakteri Pseudomonas solanacearum. Pengamatan di lapang hanya dihitung banyaknya tanaman yang terserang. Hasil pengamatan disajikan pada Tabel 4.

Berdasarkan hasil pengamatan di lapang dan hasil observasi ke daerah-daerah di kab. Bondowoso, maka varietas lokal yang terbaik 
Tabel 4. Jumlah Tanaman Terserang dan Terpanen pada Berbegai Varietas Tembakau yang Diuji di Kec.Tegal Ampel, Kab. Bondowoso pada Tahun 2009

\begin{tabular}{llllll}
\hline \multirow{2}{*}{ Varietas } & \multicolumn{2}{l}{$\begin{array}{l}\text { Jumlah tanaman } \\
\text { terserang (tanaman) }\end{array}$} & & & \multirow{2}{*}{ Jumlah } \\
\cline { 2 - 5 } & 3 minggu & 6 minggu & 9 minggu & 10 minggu & tanaman terpanen \\
\hline Sam1 & $2,67 \mathrm{~b}$ & $27,00 \mathrm{~b}$ & $46,33 \mathrm{ab}$ & $53,00 \mathrm{bc}$ & $109,67 \mathrm{a}$ \\
Se2 & $6,30 \mathrm{a}$ & $53,67 \mathrm{a}$ & $80,00 \mathrm{a}$ & $90,00 \mathrm{a}$ & $50,00 \mathrm{ab}$ \\
Mar3 & $3,67 \mathrm{ab}$ & $35,00 \mathrm{ab}$ & $66,00 \mathrm{a}$ & $85,33 \mathrm{ab}$ & $36,00 \mathrm{ab}$ \\
Sam4 & $5,00 \mathrm{ab}$ & $11,33 \mathrm{ab}$ & $21,67 \mathrm{~b}$ & $41,64 \mathrm{c}$ & $71,00 \mathrm{ab}$ \\
Sam5 & $6,00 \mathrm{ab}$ & $14,67 \mathrm{~b}$ & $29,00 \mathrm{~b}$ & $41,00 \mathrm{c}$ & $111,00 \mathrm{a}$ \\
Sam 6 & $6,30 \mathrm{a}$ & $13,00 \mathrm{~b}$ & $28,00 \mathrm{~b}$ & $41,67 \mathrm{c}$ & $91,67 \mathrm{ab}$ \\
\hline KK (\%) & 35,6 & 48,58 & 41,58 & 33,03 & 45,30 \\
\hline
\end{tabular}

adalah Sam1, Sam5 dan Sam6 yang memiliki mutu baik. Kelebihan Sam1, Sam4, Sam5 dan Sam6 adalah warna tembakau setelah disimpan lama semakin bagus, sedang Mar3 pada saat panenan baru warna menarik tetapi setelah disimpan lama warnanya semakin kurang menarik, selain itu Mar3 memiliki ketahanan yang rendah. Oleh karena itu, walaupun Mar3 memiliki indeks mutu tinggi tetapi tidak terpilih karena termasuk varietas yang rentan.

Dengan demikian, varietas yang terpilih adalah Sam1, sedang Se2 pada saat panenan baru dan setelah disimpan warnanya kurang menyenangkan. Oleh karena itu varietas yang terpilih adalah Sam1, Sam5 dan Sam6.

\section{SIMPULAN}

Dari enam varietas yang diuji, tiga varietas lokal memliiki kelebihan yang seimbang, dari segi potensi produksi, indeks mutu, indeks tanaman, kadar nikotin dan serangan penyakit, yaitu Sam1, Sam5 dan Sam6, dengan daya hasil masing-masing $1.682 \mathrm{~kg} / \mathrm{ha}, 1.399 \mathrm{~kg} / \mathrm{ha}$ dan $1.282 \mathrm{~kg} / \mathrm{ha}$.

\section{DAFTAR PUSTAKA}

Allard, R.W. 1989. Pemuliaan Tanaman jilid I. Penerbit Bina Aksara. Jakarta. Anggota IKAPI.

Crowder, L.V. 1986. Genetika Tumbuhan. Penerbit Gajah Mada University Press.

Herwati A., Abdul R.S.K dan Slamet, 1993. Penampilan Beberapa Karakter Agronomis Tiga Galur Hasil Seleksi Tembakau Kultivar DB 101. Zuriat 4 (2); 23-30

Kalshoven, L.G.E. 1981. The Pests Of Crops In Indonesia. Rev. P.A. Van der Laan. hal 701. Jakarta

Mangoendidjojo, W. 2003. Dasar-dasar Pemuliaan Tanaman. Penerbit Kanisius. Yogyakarta

Semangun, H., 1991. Penyakit-penyakit Tanaman Perkebunan di Idonesia. Yogya- karta: Gadjah Mada University Press. Yogyakarta

Suwarso, 1981. Dasar-Dasar Seleksi dan Implikasinya dalam Praktek. Kumpulan Seminar No. 12 Balittri 1981

Suwarso, 1992. Pemuliaan tembakau virginia dan tembakau asli. Prosiding simposium pemuliaan Tanaman I. Peripi Komda Jatim hal 264-278

Suwarso, Anik Herwati, dan Rusim Mardjono, 2004. Uji multi lokasi galur harapan dan varietas introduksi tembakau Virginia. Prosiding Diskusi Panel Revitalisasi system agribisnis tembakau bahan baku rokok.12 Oktober 2004. Malang

Suwarso, Anik Herwati, Soekirno dan Subiyakto, 1996. Potensi Hasil Dan Mutu Galur Harapan Tembakau Madura di Kab. Sumenep dan Pamekasan. Jurnal Penelitian Tanaman Industri 1 (5): 77-83

Suwarso, Samsuri, Titiek yulianti, Suharto, Suseno, M. Yasin, 2010. Uji produktivitas dan mutu tiga varietas tembakau oriental di Indonesia. Jurnal littri 16 (3): 112 - 118

Yulaikah, S. 2008. Eksplorasi Varietas Lokal Tembakau Bondowoso. Simposium V Litbang Perkebunan. Bogor 14 Agustus 2009. 